\title{
Parental Social Support and Achievement Motivation on Self- Regulated Learning Strategy with an Interest as a Mediator Variable
}

\begin{abstract}
Dhanu Saputra ${ }^{1 *}$, Daliman²
1,2 Magister Psikologi, Universitas Muhammadiyah Surakarta, Surakarta, Indonesia

*e-mail: saputradhanu11@gmail.com

Abstract

Social cognitive theory explains how the individual's environment can influence the emergence of intrinsic motivation which can encourage students to be able to learn independently and be able to achieve learning goals. This study aims to analyze the effect of parental social support and achievement motivation with self-regulated learning with interest as a mediator variable. This research was conducted in 3 different schools. The number of the population in this study amounted to 730 students. While the number of samples used was 288 students. The sampling technique in this study used purposive sampling technique with the criteria for assessing favorite, ordinary and less favorite schools based on the assessment of the surrounding community. The data analysis technique used is the Structural Equation Modeling (SEM) model with the AMOS program. The results of this study indicate that there is a significant influence between social support and achievement motivation on interest. There is a significant influence between social support, achievement motivation and interest in self-regulated learning. There is an influence between social support and achievement motivation on self-regulated learning through interest variables. Students who have high motivation tend to apply high self-regulated learning so that students are encouraged to improve their performance, have the courage to take risks, are creative, and innovative. This can be used as a theoretical and empirical reference in developing student learning independence.
\end{abstract}

Keywords: Parental Social Support, Achievement Motivation, Self-Regulated Learning, Interest

\section{Introduction}

Learning is the main obligation that must be carried out by students. However, not all students have good learning management or have the initiative to carry out the learning process. Students become very dependent on the presence of teachers. Student independence in learning is still a critical issue in the education field. Good independency of learning will create students successful in their learning. Learning also needs the competencies to solve problem and to have responsibility. A student is able to learn when the learning control is in the student's hand to reach the goals by self-regulating (Cahyani et al., 2019). Self-learning ability refers to goal-directed behavior (Boekaerts \& Cascallar, 2006). Research has shown that self-regulated skills (SRL) are important for problem solving, SRL skills such as monitoring and organizing learning processes are essential for learning during the school years and in the working world (Januardini et al., 2014; Macklem, 2015). Self regulated learning defined as an active and constructive process whereby learners set goals for their learning and then attempt to monitor, regulate, and control cognition, motivation and behavior that are guided and constrained by goals and contextual features in their environment (Pintrich, 2004).

Self regulated learning occurs when students direct their own learning by involving thoughts, emotions, motivation, behavior and the environment (Carneiro et al., 2012). Student's self-regulation in an academic setting is a fundamental construct that can affect student involvement in learning. Students will be successful if they rely on the level of motivation and self-regulation in the learning process (Demirören et al., 2016). The low achievement of students in school is due to the lack of self-regulation in learning from each individual (Daniela, 2015). This is because self-regulated learning is considered the key to

\footnotetext{
${ }^{*}$ Corresponding author.
}

Received October 26, 2020; Accepted April 24, 2021; Available online September 25, 2021 Copyright @ 2021 by Author. Published by Universitas Pendidikan Ganesha. 
success at work and as an energy for each student (Daniela, 2015). So if a student has high self-regulated learning, it will allow him to succeed in achieving his achievement, and of course this is one of the important goals of implementing education in schools.

The components self-regulated learning namely goal setting, self-motivation, attention control, planning, use of flexible learning strategies, self-monitoring, seeking appropriate assistance and self-evaluation (Ormrod, 2009). This component can measure how selfregulated learning strategies students have. The problem that often occurs in schools regarding self-regulated learning has been proven by previous researchers by conducting interviews with the Deputy Principal of SMP X Surakarta, which resulted in the difficulty of conditioning students in the classroom due to a lack of awareness and student learning responsibility which was shown by being late in collecting assignments and often cheating. In addition, students who have learning difficulties do not have the initiative to ask friends or teachers, learning activities are only carried out during exams and doing assignments, the rest of the students only play cellphones (games and internet browsing) and hang out, so the learning outcomes are not satisfactory. Students tend not to have strategies in learning, often procrastinate, and have no future goals, so they have less responsibility in learning (Ambarsari et al., 2017).

Family is the main and first pillar in forming child to be independent (Santrock, 2010). The greatest support in the home environment comes from parents. Parents are expected to provide opportunities for children to develop their abilities. The social support obtain from parents will be felt by adolescents as a feeling tendency to be calmer when faced with a problem. This social support can be in the form of emotional support, appreciation support, instrumental support, information support or support from the closest group, namely the family (Amini \& Salim, 2020). The results of previous research regarding Self-Regulated Learning (SLR) explained that students who have high learning motivation will have the high ability to self-regulated learning. Students will try to try every given task even though it is difficult to do. Motivated students desire success, and when they fail will double their efforts so they can succeed. They are motivated to plan, organize, monitor, evaluate and even use the environment to support their learning activities. On the other hand, students who have low learning motivation will have low self-regulated learning ability, where students will feel reluctant performing the assigned task when he knows that he is unable to do it, without any effort. This reluctance makes students unable to plan or regulate their thoughts, behavior and emotions which causes students to be more likely to be defensive such as choosing to skip, cheating and so on (Mulyana et al., 2015).

Findings from previous research indicate that student motivation to learn is related to the use of independent learning strategies (SRL) in academic settings (Latipah, 2015). Next research got the results that a significant relationship was found between self-regulated learning (SRL) and motivation. It can be understood that self-regulation learning and motivation exist to clarify student success in the classroom. When students are motivated to learn, they are more likely to so they are often more motivated to complete learning tasks. The findings of this study indicate that if students are motivated to learn, they spend more time learning and using SRL strategy.Academic self-regulation is a learning process as resulted by cognitive regulation and their achievement. SRL is an accompanying process students in regulating their thoughts, behavior, and emotions to navigate their learning experiences successfully (Schunk \& Zimmerman, 2012). The regulation of students' thoughts, behavior and emotions includes the students' motivation and interest in learning to be successful in achieving their learning outcomes.

Several studies in several schools in Nigeria revealed that the ability to study independently or academic self-regulation (SRL) is an important factor that can affect student academic success (Olakanmi \& Gumbo, 2017). It is important for schools in Nigeria to generate student interest in learning through SRL (Olakanmi \& Gumbo, 2017). Therefore, students' mental abilities in the form of interest can influence student self-regulation or students' independent learning ability. Regarding the explanation of theory and the results of previous studies, the researchers assume that with the high social support provided by parents to students, it will convince students that each individual has the ability to organize 
learning independently, besides that students who have high motivation to excel will be more active in organize and encourage himself to be able to develop independent learning strategies, in addition to these two things Such interest is one of the things that can improve or worsen academic self-regulation. This study aims to analyze the effect of parental social support and achievement motivation with self-regulated learning with interest as a mediator variable.

\section{Method}

This study is a cross section, correlational study, which looked at the relationship between more than two variables. This research was conducted in the city of Surakarta by involving 3 different schools, namely SMPN 10 Surakarta, SMPN 24 Surakarta, and SMPN 9 Surakarta. The number of the population in this study amounted to 730 students. While the number of samples used was 288 students. The sampling technique in this study used purposive sampling technique with the criteria for assessing favorite, ordinary and less favorite schools based on the assessment of the surrounding community. This research data collection technique using 4 research scales which include self-regulated learning scale, social support scale, achievement motivation scale and interest scale. The data validity technique in this study used the Cronbach Alpha coefficient reliability test. The data analyze technique used is Structural Equation Modeling (SEM) model utilizing AMOS program.

\section{Result and Discussion}

\section{Results}

Estimation analysis is done by analyzing the full-model to see the suitability of the model and the causality relationship built into the model being tested. The full model is done by replacing the two correlation arrows with one arrow representing the hypothesis given in this study. Model suitability testing is evaluated through a review of various goodness of fit criteria. For this reason, the first action taken is to evaluate whether the data used can meet the assumptions required in the SEM analysis. When these assumptions are met, the model can be tested. Some of the important measurements in evaluating the goodness-of-fit criteria along with the cut-of value are shown in Table 1.

Table 1. Model Accuracy Test (Goodness of Fit Model)

\begin{tabular}{llll}
\hline Goodness of index & Cut-off Value & Estimation Results & Information \\
\hline Chi-square $(X 2)$ & Expected & 810.057 & Not good \\
Significance Probability $(p)$ & $\geq 0.05$ & 0.000 & Not good \\
RMSEA & $\leq 0.08$ & 0.102 & Not good \\
GFI & $\geq 0.90$ & 0.769 & Not good \\
AGFI & $\geq 0.90$ & 0.712 & Not good \\
CMIN / DF & $\leq 2.00$ & 3.990 & Not good \\
TLI & $\geq 0.95$ & 0.893 & Pretty good \\
CFI & $\geq 0.95$ & 0.906 & Pretty good \\
\hline
\end{tabular}

The Chi-Square value is equal to 810,057 with a probability value ( $p$-value) of 0.000 $(p<0.05)$. The GFI value is 0.769 less than 0.90 , then the $\mathrm{Cmin} / \mathrm{df}$ value is 3,990 or above 2 , the RMSEA value of 0,102 is above 0.08 . Furthermore, the TLI value is 0.9893 and CFI is 0.906 below 0.95 , the AGFI value is 0.712 above the recommended value of 0.90 . Based on the results of the analysis, the model is declared marginally feasible. Testing is done by looking critical ratio on regression weight. The hypothesis test in this study shown in Table 2. 
Table 2. Hypothesis Test of Regression Weights: (Group number 1 - Default model)

\begin{tabular}{|c|c|c|c|c|c|c|c|}
\hline & & & Estimate & SE & CR & $\mathbf{P}$ & Label \\
\hline Interest & $<---$ & Social_Support & 0.088 & 0.020 & 4.325 & 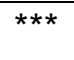 & par_18 \\
\hline Interest & $<---$ & $\begin{array}{l}\text { Achievement } \\
\text { motivation }\end{array}$ & 0.135 & 0.016 & 8.194 & $* \star *$ & par_19 \\
\hline Self_Regulated_Learning & $<---$ & Interest & 0.693 & 0.176 & 3.930 & $* * *$ & par_20 \\
\hline Self_Regulated_Learning & $<---$ & Social_Support & 0.217 & 0.054 & 4.047 & $* \star *$ & par_21 \\
\hline Self_Regulated_Learning & $<---$ & $\begin{array}{l}\text { Achievement } \\
\text { motivation }\end{array}$ & 0.488 & 0.052 & 9.473 & $* * *$ & par_22 \\
\hline
\end{tabular}

The direct effect is indicated by an arrow on the diagram and is in accordance with the given hypothesis. The direct effects on this research model as shown on Table 3.

Table 3. Direct Effect

\begin{tabular}{lll}
\hline & Interest & Self-regulated learning \\
\hline Social support & 0.088 & 0.217 \\
Achievement motivation & 0.139 & 0.488 \\
Interest & - & 0.693 \\
\hline
\end{tabular}

Based on the Table 3, it can be seen that there is a direct influence between support social against the interest values 0.088 ; the influence of achievement motivation on interest is equal to 0.139 and the effect of interest on self-regulated learning is equal to 0.693 . Meanwhile, the direct influence between social support against self-regulated learning amounting to 0.217 ; the effect of achievement motivation on self-regulated learning is equal to 0.488 . Based on the results of the analysis, it appears that the highest effect is interest in self-regulated learning, which is 0.693 . The advantage of SEM is that it is able to identify the indirect effect between exogenous constructs and endogenous constructs that are not addressed with arrows directly. Based on the data analysis, it can be seen that social support has an indirect effect on self-regulated learning amounting to 0.056 and there is also an indirect effect between achievement motivation on self-regulated learning of 0.153 . This empirical evidence also proves that the effect of achievement motivation on self-regulated learning through interest is higher than the effect of social support on self-regulated learning through interest $(0.121>0.056)$.

\section{Discussion}

Based on the results of the analysis on the first hypothesis regarding the effect of social support on interest. It is known that there is a significant influence between social support on interest, this is evidenced by the value of the critical ratio (cr) between social support and interest of 4,325, this value is greater than 1.96. Because the value of $\mathrm{cr}$ is greater than $1.96(4,325>1.96)$, it can be concluded that social support has a significant effect on interest. Then the amount of direct influence between social support on interest is 0.088 . The interest that is owned by a person can be the basis for carrying out an activity, so that maximum results can be obtained. Interests play a role in pushing a person to achieve his goals. Great interest and desire will automatically be supported by the people around them (Mulyana et al., 2015). Encouragement in the form of support from people around will be very helpful to be able to give attention to what is desired. The support provided by those around is commonly referred to as social support.

Social support is the degree of support provided to individuals, especially when needed by people who have a close emotional relationship with that person (Maslihah, 2011). Social support can refer to comfort, care, self-respect or any form of assistance received by individuals from other people or groups. Social support comes from various parties, such as from family, spouses, friends, coworkers, superiors, as well as from doctors 
or psychologists. Social support is a physical and psychological comfort provided by friends or family members (Baron \& Byrne, 2005). The results of previous research found that social support from parents is by providing positive support for the child's learning process such as appreciating their thoughts and feelings felt by students, willing to share feelings, provide examples and become models for students to deal with their own feelings in an appropriate way and provide opportunities for students to try to solve their own problems (Tarmidi \& Rambe, 2010).

In the second hypothesis regarding the effect of achievement motivation on interest, it is known that there is a significant influence between achievement motivation and interest, this is evidenced by the value of the critical ratio $(\mathrm{CR})$ between achievement motivation and interest of 8.194, this value is greater than 1.96. Because the value of $\mathrm{cr}$ is greater than 1.96 $(8,194>1.96)$, it can be concluded that achievement motivation has a significant effect on interest. Then, the magnitude of the direct influence of achievement motivation on interest is 0.139 . Achievement motivation is a person's tendency to achieve success or obtain what is the desired end goal, individual involvement in a task, hope to succeed in a given task, and the urge to face obstacles to do jobs quickly and precisely (Chaplin, 2006). Achievement motivation as an effort, a determination to get the best and maximum result with all the abilities of an individual, to continue to progress even if it is successful or fail but still feel satisfied and proud of what he has done (Fakhria \& Setiowati, 2017). Achievement motivation has a big role in the achievements of a person. Achievement motivation is one of the requirements for learning and it is something that intensifies behavior and provides direction so that learning goals are achieved (Mousavi \& Abedini, 2016). Students who carry out academic SRL will be more effective if they are highly motivated. In social cognitive theory, it explains how the individual's environment can influence the emergence of intrinsic motivation which can encourage students to be able to learn independently and is believed to be the key to success in learning (Lee et al., 2014).

In the third hypothesis regarding the effect of social support on self-regulated learning, it is known that there is a significant influence between social support on selfregulated learning, this is proved by the value of the critical ratio (cr) between social support and self-regulated learning of 8.194 , this value is greater from 1.96. Because the value of $\mathrm{cr}$ is greater than $1.96(8,194>1.96)$, it can be concluded that social support has a significant effect on self-regulated learning. The amount of direct influence between social support on self-regulated learning is 0.217 . SRL as an active and constructive process in which learners set goals for their learning and then try to monitor, regulate, and control cognition, motivation and behavior, guided and limited by their goals and environment (Pintrich, 2004). Individuals who have the ability to organize themselves exhibit quality in achieving their goals, they consciously use strategies to succeed, they plan, control, and direct their mental efforts, they use their self-confidence and emotions in increasing their achievement, they control their effort and time, they choose a work environment that is suitable for themselves (Schunk \& Zimmerman, 2012). Social support is an important thing that can influence self-regulated learning. Social support in this case can be in the form of emotional support, appreciation, instrumental, and informative. If emotional support is high, the individual will feel a high level of encouragement from family and community members and if the appreciation for the individual is high, it will increase the self-confidence. Students who feel emotional social support feel relieved because their parents, teachers, and friends pay attention to the suggestions or pleasing impressions of them, so that they can find solutions to solve problems in learning (Mahmudi \& Suroso, 2014).

Then, in the fourth hypothesis regarding the effect of achievement motivation on selfregulated learning, it is known that there is a significant influence between achievement motivation on self-regulated learning, this is evidenced by the value of the critical ratio (cr) between achievement motivation and self-regulated learning of 9.473 , this value is greater than 1.96. Because the value of $\mathrm{cr}$ is greater than $1.96(9,473>1.96)$, it can be concluded that achievement motivation has a significant effect on self-regulated learning. The magnitude of the direct effect of achievement motivation on self-regulated learning is 0.488 . The most important motivation for educational psychology is achievement motivation 
(Yustika, 2015). When someone considers achievement as a necessity, then he already has the motivation to achieve. A person tends to strive for success or choose a goal-oriented activity for success or failure. This achievement motivation is needed by students to achieve the desired academic standards. With an achievement motivation, students can apply selfregulated learning properly because achievement motivation moves students to set goals in the form of the need for achievement in learning, has the initiative in planning, learning procedures, and acts towards achievement. Achievement motivation is needed by students to achieve the desired academic standards. The existence of high achievement motivation in students is a requirement so that students are motivated by their own abilities to overcome the various learning difficulties they face, and further students will be able to learn on their own. The results of this study are in line with research which found that there was a significant influence between achievement motivation and self-regulated learning (Yustika, 2015; Zheng \& Li, 2016).

Furthermore, in the fifth hypothesis regarding the effect of interest on self-regulated learning, it is known that there is a significant influence between interest in self-regulated learning, this is evidenced by the value of the critical ratio (cr) between interest and selfregulated learning of 3,930 , this value is greater than 1.96. It is because the cr value is greater than $1.96(3,930>1,96)$, it can be concluded that interest has a significant effect on self-regulated learning. The amount of direct influence between interest in self-regulated learning is 0.693 . Interest is a feeling of liking and attracted to something or activity, without being asked (Slameto, 2013). Interest is basically the acceptance of a relationship between and something outside someone. The bigger the relationship, the greater the interest. Interest can also be interpreted as the acceptance of a relationship between and outside of oneself. Interest has a huge influence on student learning activities. Students who are interested in a lesson will tend to study it seriously because of the attraction for them. This means that interest can provide a direction for someone to do an action and indirectly interest also encourages children or students to act. The results of this study are in line with research who found that there was a significant influence between interest in self-regulated learning (Rachmandasari, 2012).

In the sixth hypothesis regarding the effect of social support on self-regulated learning through interest, it is known that there is a significant influence between social support on self-regulated learning through interest. This is evidenced by the value of the critical ratio (cr) between social support and self-regulated learning through interest of 2.934 , this value is greater than 1.96. Since the value of $\mathrm{cr}$ is greater than $1.96(2,934>1.96)$, it can be concluded that social support has a significant effect on self-regulated learning through the interest variable. The magnitude of the indirect effect of social support on self-regulated learning is 0.056 . One of the factors that influence self-regulated learning is the environment. The environment plays a very important role in the growth and development of children's interest in learning (Schunk \& Zimmerman, 1998). Through interaction with their environment, children can develop their interest in learning. Through association, someone will be influenced by his interests. This is in accordance with the opinion which states that interest can be obtained from children's experiences from the environment in which they live (Abror, 2004). The environment is a family as a place to raise children, a school where to educate, and a community where they can hang out and play in their daily lives. However, the closest environment is family, because family is the first place children recognize. Therefore parents have an obligation to educate and direct children towards a better direction. Based on this, it can be concluded that there is a significant influence between social support on self-regulated learning through interest variables.

Then, in the seventh hypothesis regarding the effect of achievement motivation on self-regulated learning through interest, it is known that there is a significant influence between achievement motivation on self-regulated learning through interest. This is evidenced by the value of the critical ratio (cr) between achievement motivation and selfregulated learning through interest of 3.568, this value is greater than 1.96. Because the value of $\mathrm{cr}$ is greater than 1.96 (3.568> 1.96), it can be concluded that achievement motivation has a significant effect on self-regulated learning through the interest variable. 
The magnitude of the indirect effect of achievement motivation on self-regulated learning is 0.153 . One aspect of self-regulated learning is intrinsic motivation (Schunk \& Zimmerman, 2012). It arises from within the individual himself without coercion or encouragement from others, but on the basis of his own volition. Achievement motivation has a big role in the achievements of a person. Previous study found that people who have high achievement motivation will have better performance when compared to those who have low achievement motivation (Walgito, 2010). Thus it can be argued that to predict how a person's performance can be seen from his achievement motivation. Other study also found that student motivation to learn is related to the use of SRL in academic settings (Abdulhay \& Sarkeshikian, 2015). When students are motivated to learn, they are more likely to so they are often more motivated to complete learning tasks. In addition, students will also spend more time studying and using the SRL strategy.

Based on the research results, it can be concluded that there is a relationship between achievement motivation and parental social support with independent learning strategies through interest as a mediator. Based on the results of the analysis, it is known that the highest direct effect is in the interest variable on self-regulated learning, which is 0.693. While the highest indirect effect is found in the variable of achievement motivation on self-regulated learning through interest, this is evidenced by the magnitude of the indirect effect of achievement motivation on self-regulated learning through interest which is 0.121 which is higher than the effect of social support on self-regulated learning through interest. amounting to 0.056 . The motivation that learners have is positively related to self-regulated learning. Motivation is needed by students to implement strategies that will affect the learning process (Zheng \& Li, 2016). Individuals who have high achievement motivation always show their best work results with the aim of achieving the best predicate and their behavior is future-oriented. Meanwhile, individuals who have low achievement motivation assume that the best predicate is not the main goal and this makes the individual not trying as much as possible in completing his task, encouraged to takes risks, and is creative and innovative.

\section{Conclusions and Suggestions}

Based on the results of the analysis and discussion, it can be concluded that there is a significant influence between social support on interest. There is a significant influence between achievement motivation. There is a significant influence between social support on self-regulated learning. There is a significant influence between achievement motivation on self-regulated learning. There is a significant effect that interest has a significant effect on self-regulated learning. There is an effect between social support and a significant effect on self-regulated learning through interest variables. There is an effect between achievement motivation and a significant effect on self-regulated learning through interest variables. Achievement motivation has a higher effect on self-regulated learning compared to social support. Therefore, it is hoped that students can increase their achievement motivation so that it is easier to achieve the desired goals. For schools, it is hoped that the school can continue to motivate students in increasing learning independence through activities that can increase student motivation in independent learning and take the right approach so that it can stimulate student learning independence. While for parents, it is hoped that it can help students to further develop independent learning. Things that parents can do to help improve student learning independence are to provide positive support for the child's learning process such as by appreciating whatever thoughts and feelings are felt by students, willing to share their own feelings with students, provide examples and models for students and provide opportunities for students to try to solve the problem on their own.

\section{References}

Abdulhay, H., \& Sarkeshikian, S. A. H. (2015). Motivational facets of self-regulated learning: self-efficacy as a predictor of resource management strategies in Iranian TEFL students. Journal of Scientific Research and Development, 2(5), 203-210. 
https://www.academia.edu/download/37219142/31_2015-2-5-203-210.pdf.

Abror, R. (2004). Psikologi Pendidikan (4th ed.). PT Tiara Wacana.

Ambarsari, J., Ruhaena, L., \& Uyun, Z. (2017). Efektivitas Pelatihan Manajemen Diri Untuk Meningkatkan Kemampuan Belajar Dengan Refulasi Diri (Self Regulated Learning) Siswa SMP. Universitas Muhammadiyah Surakarta.

Amini, D. S., \& Salim, R. M. A. (2020). Dukungan Orangtua, Efikasi Diri Pengambilan Keputusan Karier, Dan Planned Happenstance Pada Siswa Sekolah Menengah Pertama. Jurnal Psikologi Ulayat: Indonesian Journal of Indigenous Psychology, 7(1), 87-98. https://doi.org/10.24854/jpu02019-294.

Baron, R. A., \& Byrne, D. (2005). Psikologi Sosial. Erlangga.

Boekaerts, M., \& Cascallar, E. (2006). How far have we moved toward the integration of theory and practice in self-regulation? Educational Psychology Review, 18(3), 199210. https://doi.org/10.1007/s10648-006-9013-4.

Cahyani, B. H., Alsa, A., Ramdhani, N., \& Khalili, F. N. (2019). The role of classroom management and mastery goal orientation towards student's self-regulation in learning Mathematics. Psikohumaniora: Jurnal Penelitian Psikologi, 4(2), 117-128. https://doi.org/10.21580/pjpp.v4i2.3576.

Carneiro, R., Lefrere, P., Steffens, K., \& Underwood, J. (2012). Self-regulated learning in technology enhanced learning environments (5th ed.). Springer Science \& Business Media.

Chaplin, J. P. (2006). Kamus lengkap psikologi (Terjemahan Kartini Kartono). PT Raja Grafindo Persada.

Daniela, P. (2015). The relationship between self-regulation, motivation and performance at secondary school students. Procedia-Social and Behavioral Sciences, 191, 25492553. https://doi.org/10.1016/j.sbspro.2015.04.410.

Demirören, M., Turan, S., \& Öztuna, D. (2016). Medical students' self-efficacy in problembased learning and its relationship with self-regulated learning. Medical Education Online, 21(1), 1-10. https://doi.org/10.3402/meo.v21.30049.

Fakhria, M., \& Setiowati, E. A. (2017). Motivasi berprestasi siswa ditinjau dari fasilitasi sosial dan ketakutan akan kegagalan. Psikohumaniora: Jurnal Penelitian Psikologi, 2(1), 29-42. https://doi.org/10.21580/pjpp.v2i1.1279.

Januardini, L., Hartati, S., \& Astuti, T. P. (2014). Perbedaan Self-regulated Learning Ditinjau Dari Pola Asuh Orangtua Pada Siswa Kelas VIII SMP Fransiskus Dan SMP PGRI 01 Semarang. Jurnal Psikologi, 12(2). https://doi.org/10.14710/jpu.12.2.

Latipah, E. (2015). Strategi self regulated learning dan prestasi belajar: kajian meta analisis. Jurnal Psikologi, 37(1), 110-129. https://doi.org/10.22146/jpsi.7696.

Lee, W., Lee, M.-J., \& Bong, M. (2014). Testing interest and self-efficacy as predictors of academic self-regulation and achievement. Contemporary Educational Psychology, 39(2), 86-99. https://doi.org/10.1016/j.cedpsych.2014.02.002.

Macklem, G. L. (2015). Boredom in the classroom: Addressing student motivation, selfregulation, and engagement in learning (1st ed.). Springer.

Mahmudi, M. H., \& Suroso, S. (2014). Efikasi Diri, Dukungan Sosial dan Penyesuaian Diri Dalam Belajar. Persona: Jurnal Psikologi Indonesia, 3(02). http://jurnal.untagsby.ac.id/index.php/persona/article/view/382.

Maslihah, S. (2011). Studi tentang hubungan dukungan sosial, penyesuaian sosial di lingkungan sekolah dan prestasi akademik siswa SMPIT Assyfa Boarding School Subang Jawa Barat. Jurnal Psikologi, 10(2), 103-114. https://doi.org/10.14710/jpu.10.2.103-114.

Mousavi, S. K., \& Abedini, M. (2016). The effect of academic achievement and learning strategies on self-efficacy of the third grade high school female student (case study: the education office, District One, Kerman). Mediterranean Journal of Social Sciences, 7(2 S2), 241. https://doi.org/10.5901/mjss.2016.v7n2s2p241.

Mulyana, E., Mujidin, \& Bashori, K. (2015). Peran Motivasi Belajar, Self Efficacy Dan Dukungan Sosial Keluarga Terhadap Self-Regulated Learning Pada Siswa. Jurnal Fakultas Psikolgi. Universitas Ahmad Dahlan, 4, 165-173. 
https://core.ac.uk/download/pdf/295348723.pdf.

Olakanmi, E. E., \& Gumbo, M. T. (2017). The Effects of Self-Regulated Learning Training on Students' Metacognition and Achievement in Chemistry. International Journal of Innovation in Science and Mathematics Education (Formerly CAL-Laborate International), 25(2). https://openjournals.library.sydney.edu.au/index.php/CAL/article/view/11341.

Ormrod, J. E. (2009). Psikologi Pendidikan (6th ed.). Erlangga.

Pintrich, P. R. (2004). A conceptual framework for assessing motivation and self-regulated learning in college students. Educational Psychology Review, 16(4), 385-407. https://doi.org/10.1007/s10648-004-0006-x.

Rachmandasari, F. (2012). Pengaruh Self-Regulated Learning Dan Minat Belajar Siswa Terhadap Prestasi Belajar IPS Siswa Kelas VIII SMP Negeri 1 Kalijambe Sragen Tahun Pelajaran 2011/2012. Universitas Muhammadiyah Surakarta.

Santrock, J. W. (2010). Child Development: An Introduction. McGraw-Hill Education.

Schunk, D. H., \& Zimmerman, B. J. (1998). Self-regulated learning: From teaching to selfreflective practice. Guilford Press.

Schunk, D. H., \& Zimmerman, B. J. (2012). Motivation and self-regulated learning: Theory, research, and applications. Routledge.

Slameto. (2013). Belajar dan Faktor-faktor yang mempengaruhinya. PT Rineka Cipta.

Tarmidi, T., \& Rambe, A. R. R. (2010). Korelasi Antara Dukungan Sosial Orang Tua dan Self-Directed Learning pada Siswa SMA. Jurnal Psikologi, 37(2), 216-223. https://journal.ugm.ac.id/jpsi/article/download/7733/5983.

Walgito, B. (2010). Pengantar Psikologi Umum. Penerbit Andi.

Yustika, M. S. (2015). Hubungan antara Motivasi Berprestasi dengan Self Regulated Learning pada Siswa SMA Negeri 2 Wonogiri. Universitas Muhammadiyah Surakarta.

Zheng, L., \& Li, X. (2016). The Effects of Motivation, Academic Emotions, and SelfRegulated Learning Strategies on Academic Achievements in Technology Enhanced Learning Environment. 2016 IEEE 16th International Conference on Advanced Learning Technologies (ICALT),
https://ieeexplore.ieee.org/abstract/document/7757002/. 